\title{
ROMANTISME SISTEM HUKUM DI INDONESIA : KAJIAN ATAS KONSTRIBUSI HUKUM ADAT DAN HUKUM ISLAM TERHADAP PEMBANGUNAN HUKUM DI INDONESIA
}

\author{
(The Romanticism of Legal Systems in Indonesia: The Study of The Constribution of Islamic Law And \\ Islamic Law for Legal Development In Indonesia)
}

\author{
Zaka Firma Aditya \\ Pusat Penelitian dan Pengkajian Perkara \\ Mahkamah Konstitusi Republik Indonesia \\ Jalan Medan Merdeka Barat Nomor 6, Jakarta Pusat \\ Email: zaka.aditya@gmail.com \\ Rizkisyabana Yulistyaputri \\ Pusat Penelitian dan Pengkajian Perkara \\ Mahkamah Konstitusi Republik Indonesia \\ Jalan Medan Merdeka Barat Nomor 6, Jakarta Pusat \\ Email: yulistyaputri18@gmail.com
}

Naskah diterima: 29 Januari 2019; revisi: 18 Februari 2019; disetujui: 19 Maret 2019

\begin{abstract}
Abstrak
Sebagai negara hukum, Indonesia menganut tiga sistem hukum sekaligus yang hidup dan berkembang di masyarakat yakni sistem hukum civil, sistem hukum adat, dan sistem hukum Islam. Ketiga sistem hukum tersebut saling melengkapi, harmonis dan romantis. Hukum Islam mempengaruhi corak hukum di Indonesia karena mayoritas penduduk di Indonesia menganut agama Islam yang memungkinkan hukum Islam menjadi bagian yang penting dan berpengaruh dalam sistem hukum di Indonesia. Sedangkan hukum adat sebagai hukum yang asli yang tumbuh dan berkembang dari kebiasaankebiasaan masyarakat mempengaruhi proses berlakunya hukum di Indonesia. Bahkan, nilai-nilai yang terkandung dari hukum adat dan hukum Islam di Indonesia digunakan dalam pembentukan yurisprudensi di Mahkamah Agung. Tulisan ini akan menjelaskan bagaimana hukum adat dan hukum Islam yang berkarakter "tidak tertulis" mampu mengisi legal gap dari sistem hukum civil Indonesia. Metode penelitian yang digunakan dalam tulisan ini adalah metode penelitian hukum normatif dan menggunakan beberapa pendekatan yakni pendekatan undang-undang, pendekatan perbandingan, dan pendekatan sejarah. Tulisan ini menyimpulkan bahwa pluralisme hukum yang ada di Indonesia dapat menjadi solusi dari adanya legal gap yang tercipta karena kekakuan penerapan hukum civil. Kekakuan tersebut dapat diatasi dengan fleksibilitas dari norma dan nilai yang terdapat dalam hukum adat dan hukum Islam, sehingga dapat menciptakan ketertiban di masyarakat.
\end{abstract}

Kata kunci: sistem hukum, legal gap, nilai, hukum adat, hukum islam

\begin{abstract}
As a legal state, Indonesia adheres to three legal systems that live and develop in society, namely the civil law system, the adat law system, and the Islamic law system. The three legal systems are complementary, harmonious and romantic. Islamic law influences the legal style in Indonesia because the majority of the population in Indonesia adheres to Islam which allows Islamic law to become an important part and influence the legal system in Indonesia. Meanwhile, adat law as an original law that grows and develops from people's habits influences the legal application in Indonesia. In fact, the values contained in customary law and Islamic law in Indonesia are used in the establishment of jurisprudence in the Supreme Court. This paper will explain how customary law and Islamic law with "unwritten law" character are able to fill the legal gap of the Indonesian civil law system. The research method used in this paper is a normative legal research method and uses several approaches namely the law approach, comparative approach, and historical approach. This paper concludes that legal pluralism in Indonesia can be a solution to the existence of a legal gap created by the rigidity of the application of civil law. This rigidity can be overcome by the flexibility of the norms and values contained in customary law and Islamic law, so as to create order in society.
\end{abstract}

Keywords: legal system, legal gap, value, adat law, islamic law 


\section{A. Pendahuluan}

Sistem Hukum di definisikan sebagai sekumpulan sikap yang telah mengakar kuat dan terkondisikan secara historis terhadap hakikat hukum, aturan hukum dalam masyarakat dan ideologi politik, organisasi serta penyelenggaraan sistem hukum. ${ }^{1}$ Menurut Black Law Dictionary, sistem hukum diartikan sebagai:

Jurisdiction's basis of applying law consists of (1) A constitution, written or oral; (2) Primary legislation, statutes, and laws; authorized by constitutionally authorized legislative body; (3) Primary legislation authorized body enacts subsidiary legislation or bylaws; (4) Traditional practices upheld by the courts; (5) Civil, common, Roman, or other code of law as source of such principles or practices.

Sedangkan Peter de Cruz mendefinisikan sistem hukum sebagai pengoperasian sekumpulan institusi, prosedur, dan peraturan hukum. $^{2}$ Dalam arti luas, sistem hukum didefinisikan sebagai filsafat yuristik dan teknik yang sama yang digunakan oleh sejumlah negara yang secara umum memiliki kesamaan sistem hukum. Sistem hukum dalam arti luas ini menggambarkan sebuah keluarga hukum induk, seperti keluarga hukum Civil law, Common law, Adat law, Socialist law dan Islamic law.

Pemikiran tentang sistem hukum tidak terbebas dari kritisme dan telah diimplementasikan dalam berbagai macam cara meskipun tidak ada konsensus di kalangan pengamat hukum tentang apakah konsep ini murni heuristis, mendasar dan ilmiah atau kurang berguna secara teoritis dan deskriptif. Bahkan ketika konsep tersebut digunakan, belum ada kriteria klasifikasiannya. Misalnya Zweigert dan Kotz lebih memilih hanya yuristik, sedangkan Glasson dan Sarfatti terfokus pada asal usul historis sebuah sistem sebagai fitur yang membedakan atau mengidentifikasikan. Demikian juga belum ada kesepakatan berkenaan dengan pengelompokan berbagai sistem hukum. ${ }^{3}$

John Henry Merrymann dalam bukunya yang berjudul The Civil Law Tradition: An Introduction to The Legal System of Western Europe and Latin America membagi tradisi hukum ke dalam tiga kategori utama, yakni: tradisi hukum adat (common law), tradisi hukum kontinental (civil law), dan tradisi hukum sosialis (socialist law). ${ }^{4}$ Sedangkan Peter de Cruz dalam bukunya Perbandingan Sistem Hukum Common Law, Civil Law, and Socialist Law membagi tradisi hukum dalam beberapa kategori, meliputi: tradisi hukum continental, tradisi hukum anglo saxon dan amerika, tradisi hukum adat, tradisi hukum sosialis dan tradisi hukum Islam. Meskipun demikian, sejatinya hanya terdapat dua kategori utama tradisi hukum yang dianut di negaranegara kontemporer saat ini yakni eropa continental (civil law termasuk di dalamnya

1 Dalam Bahasa Yunani, sistem berasal dari kata "systema" yang dapat diartikan sebagai keseluruhan yang terdiri dari macam-macam bagian. Sementara itu, Prof. Subekti, SH menyebutkan sistem adalah suatu susunan atau tatanan yang teratur, suatu keseluruhan yang terdiri atas bagian-bagian yang berkaitan satu sama lain, tersusun menurut suatu rencana atau pola, hasil dari suatu penulisan untul mencapai suatu tujuan. Inu Kencana Syafiie, Sistem Adminitrasi Negara Republik Indonesia (SANRI), (Jakarta: Bumi Aksara, 2003), hlm. 2.

2 Peter de Cruz, Perbandingan Sistem Hukum Common Law, Civil Law, and Socialist Law, (Nusa Media: Bandung, 2010), hlm. 46.

Ibid., hlm. 49.

4 Lihat, John Henry Merryman, The Civil Law tRadition An Introduction to The Legal System of Western Europe and Latin America, Second Etidion, (Stanford-Carolina: Standford University Press, 1985). 
socialist law) dan tradisi hukum common (anglo saxon, anglo America, adat law, dan Islamic law).

Negara Indonesia yang menegaskan dirinya sebagai negara hukum sebagaimana dalam Pasal 1 ayat (3) Undang-Undang Dasar negara Republik Indonesia Tahun 1945 juga memiliki sistem hukum. Menariknya, Indonesia menganut tiga sistem hukum sekaligus yang hidup dan berkembang dalam kehidupan masyarakat maupun ketatanegaraan yakni sistem hukum civil, sistem hukum adat, dan sistem hukum Islam. Sistem hukum civil yang memiliki karakter "hukum tertulis" berkembang di Indonesia selama masa kolonial Belanda dan tetap bertahan hingga sekarang mempengaruhi produk-produk hukum saat ini. Meskipun masa kolonial telah berakhir 72 tahun yang lalu, namun benih-benihnya masih dapat dirasakan hingga sekarang ini mengingat masih eksis dan berlakunya beberapa produk hukum civil kolonial Belanda. Di bidang hukum pidana, Wetboek van Straftrechts (WvS) masih berlaku melalui Undang-Undang Nomor 1 Tahun 1947 sebagai kitab pedoman dalam bidang pidana (Kitab Undang-Undang Hukum Pidana). Di bidang Perdata, Burgerlijke Wetboek (BW) atau Kitab Undang-Undang Hukum Perdata dan Wetboek Van Kopenhandel (WvK) atau Kitab Undang-Undang Hukum Dagang masih berlaku. Sedangkan dalam bidang acara perdata, Herzien Inlandsch Reglement (HIR), Rechtsreglement voor de Buitengewesten (RBg) dan Reglement op de Burgerlijke Rechtsvordering (RR) juga masih diberlakukan dan belum ada perubahan.
Selain itu, hukum adat sebagai hukum yang asli yang tumbuh dan berkembang dari kebiasaan-kebiasaan masyarakat yang sangat mempengaruhi proses berlakunya hukum di Indonesia, dan hukum adat ini sangat beragam di Indonesia. Sehingga, dalam penerapan secara umum akan menghadapi kendala tetapi cukup efisien untuk masyarakat setempat yang memberlakukannya. Bahkan, apabila di kalkulasikan, lebih banyak masyarakat yang patuh dan tunduk pada hukum adat daripada hukum negara. Cornelis van Vollenhoven sebagai ahli pertama yang menggagas pembagian hukum adat, mengklasifikasikan 23 lingkungan adat di Nusantara yakni: Aceh, Gayo dan Batak, Nias dan sekitarnya, Minangkabau, Mentawai, Sumatra Selatan, Enggano, Melayu, Bangka dan Belitung, Kalimantan (Dayak), Sangihe-Talaud, Gorontalo, Toraja, Sulawesi Selatan (Bugis/ Makassar), Maluku Utara, Maluku Ambon, Maluku Tenggara, Papua, Nusa Tenggara dan Timor, Bali dan Lombok, Jawa dan Madura (Jawa Pesisiran), Jawa Mataraman, dan Jawa Barat (Sunda). Sementara itu, menurut Gerzt orang Amerika menyatakan bahwa masyarakat Indonesia memiliki 350 budaya, 250 bahasa dan seluruh keyakinan dan Agama di dunia ada di Indonesia. ${ }^{5}$

Menariknya, Hukum Islam juga mempengaruhi corak hukum di Indonesia karena mayoritas penduduk di Indonesia menganut agama Islam yang memungkinkan hukum Islam menjadi bagian yang penting dan berpengaruh dalam sistem hukum di Indonesia. Adanya peraturan perundang-undangan yang bernafaskan Syariah Islam seperti dalam UU

5 H. Mustaghfirin, "Sistem Hukum Barat, Sistem Hukum Adat, Dan Sistem Hukum Islam Menuju Sebagai Sistem Hukum Nasional Sebuah Ide Yang Harmoni”, Jurnal Dinamika Hukum, Volume 11, Edisi Khusus Februari (2011), hlm. 92. 
penyelengaraan Haji, UU Perbankan Syariah, UU Wakaf, UU Zakat, Kompilasi Hukum Islam (KHI) dan Peraturan Daerah Syariah (Perda Syariah) telah cukup membuktikan bahwa negara Indonesia tidak melepaskan tanggungjawab urusan beragama dengan urusan negara/ pemerintah. Sehingga dapat dikatakan bahwa hukum Indonesia dipengaruhi oleh warna hukum kontinental, hukum adat dan hukum Islam yang pada kenyataannya masing-masing mempunyai pengaruh yang besar dalam sistem hukum di Indonesia.

Tulisan ini akan mengkaji mengenai kedudukan, eksistensi dan konstrubusi hukum adat dan hukum islam dalam sistem hukum di Indonesia, yang akan dibatasi dengan rumusan masalah sebagai berikut: (1) Bagaimana sistem hukum kontinental, hukum Islam, dan hukum adat dapat mempengaruhi perkembangan sistem hukum di Indonesia?; (2) Bagaimana kedudukan hukum Islam dalam sistem hukum di Indonesia?; (3) Bagaimana kedudukan dan eksistensi hukum adat dalam sistem hukum di Indonesia?; dan (4) Bagaimana pluralisme hukum yang ada dapat menciptakan keselarasan dalam perkembangan sistem hukum di Indonesia?

Pembahasan ini menjadi menarik karena nantinya akan dapat dilihat bahwa meskipun sistem hukum kontinental menjadi pilihan utama bangsa Indonesia, namun sebenarnya produk-produk hukum yang dihasilkan tidak terlepas dari pengaruh hukum adat dan hukum Islam. Bahkan, nantinya dapat dilihat mengenai pengaruh hukum adat dalam pembentukan yurisprudensi di Mahkamah Agung.

\section{B. Metode Penelitian}

Penelitian ini merupakan penelitian hukum dengan metode hukum normatif yang bersifat preskriptif. Menurut Peter Mahmud Marzuki, di dalam penelitian hukum umumnya dikenal beberapa pendekatan penelitian yakni: pendekatan undang-undang (statute approach), pendekatan konseptual (conceptual approach), pendekatan kasus (case approach), pendekatan perbandingan (comparative approach) dan pendekatan sejarah (historical approach). Tulisan ini menggunakan pendekatan undangundang (statute approach), pendekatan perbandingan (comparative approach) dan pendekatan sejarah (historical approach). ${ }^{6}$

Pendekatan undang-undang (statute approach) dilakukan dengan menelaah semua peraturan perundang-undangan yang bersangkut paut dengan isu yang sedang dikaji yakni undang-undang dan regulasi yang berhubungan dengan sistem hukum adat dan hukum Islam. Pendekatan sejarah (historical approach) berkaitan dengan sejarah hukum (legal historis) dari sistem-sistem hukum yang ada di Indonesia. Sedangkan pendekatan perbandingan (comparative approach) dilakukan dengan cara membandingkan penerapan sistem hukum civil, sistem hukum adat, dan sistem hukum Islam di Indonesia.

\section{Pembahasan}

\section{Sistem Hukum Kontinental, Hukum Islam dan Hukum Adat di Indonesia}

Di dalam sejarahnya, sistem hukum Indonesia merupakan peninggalan dari kolonial Belanda (Eropa Kontinental/civil law) yang pernah menguasai Indonesia lebih dari 350

6 Peter Mahmud Marzuki, Penelitian Hukum (Jakarta: Kencana Media Group, 2014), hlm. 93. 
tahun, sehingga sistem hukum Belanda juga diterapkan di Indonesia berdasarkan asas konkordasi. ${ }^{7}$ Menurut Andi Hamzah, pengaruh sistem hukum Belanda ini juga mempengaruhi putusan hakim, dimana hakim di Indonesia dalam memeriksa, mengadili, dan memutus suatu perkara termasuk di dalamnya mengenai masalah penemuan hukum dipengaruhi oleh sistem hukum civil tersebut. ${ }^{8}$ Sedangkan karakteristik utama hukum civil adalah dengan adanya kodifikasi atau pembukuan hukum atau undang-undang dalam suatu kitab (code). ${ }^{9}$

Indonesia sendiri telah menundukan dirinya untuk menganut sistem hukum civil, sehingga prinsip utamanya adalah mempositipkan hukum dalam bentuk aturan tertulis atau dituangkan dalam bentuk undang-undang. Hukum yang tidak tertulis tidak diakui sebagai hukum begitu juga peraturan-peraturan yang dibuat selain oleh negara juga tidak disebut sebagai hukum akan tetapi sebagai moral masyarakat. Namun, sistem hukum civil ini dalam prakteknya memiliki banyak kelemahan karena sifatnya yang tertulis sehingga menjadi tidak fleksibel dalam mengikuti perkembangan masyarakat, cenderung kaku dan statis.

Penormaan dalam bentuk aturan tertulis dapat dikatakan merupakan bentuk pembatasan atas suatu hal yang sifatnya abstrak atau pembatasan dalam kontek materi dan dinamis atau pembatasan dalam dimensi waktu. Oleh karena itu, value consciousness masyarakat ke dalam undang-undang secara logis akan membawa suatu ketertinggalan substansi undang-undang. ${ }^{10}$ Di samping itu, banyak peraturan perundang-undangan barat yang di adopsi ke Indonesia dan diberlakukan di Indonesia, seperti Kitab Undang-Undang Hukum Pidana (KUHP), Kitab Undang-Undang Hukum Perdata (KUHP), Kitab Undang-Undang Hukum Dagang (KUHD), dengan demikian fenomena legal gab atau keterpisahan nilai-nilai masyarakat Indonesia dengan nilai-nilai peraturan perundang-undangan merupakan persoalan yang mendasar dan secara substansif hukum Indonesia akan selalu menjadi konsekuensi lanjutan yang sulit untuk dihindari. ${ }^{11}$

Sistem Hukum civil juga menjadikan para hakim sebagai corong undang-undang sebagaimana dikatakan oleh Montesquieu, artinya hakim hanya menegakkan hukum sebagaimana yang tertulis di dalam undangundang. Sistem Hukum civil ini mengikuti filsafat positivisme hukum yang menyatakan bahwa tujuan utama hukum adalah kepastian hukum bukan keadilan dan atau kemanfaatan, karena filsafat positivisme mengutamakan halhal yang sifatnya jelas dan pasti (positif) di atas segalanya dengan beragomentasi bahwa hanya

Berlakunya BW di wilayah Hindia Belanda pada waktu itu adalah berdasarkan asas konkordansi/concordantie beginsel yang tercantum di dalam Pasal 131 Indische Staatsregeling, yang biasa disingkat dengan IS. Asas tersebut menentukan bahwa bagi setiap orang Eropa yang berada diwilayah Hindia Belanda berlaku hukum perdata yang berlaku di negeri Belanda. Pasal 131 IS ini juga sekaligus merupakan dasar hukum berlakunya BW dan WvK di wilayah Hindia Belanda. Lihat Ansori Ahmad, Sejarah dan Kedudukan BW di Indonesia, (Jakarta: Rajawali, 1986).

8 Andi Hamzah, Asas-Asas Hukum Pidana, (Jakarta: PT. Rinek Cipta, 2010), hlm. 3.

9 Dalam pandangan Wirjono Prodjodikoro, adanya suatu kodifikasi tidak menutup kemungkinan juga untuk dibuatnya suatu undang-undang tersendiri mengenai delik-delik tertentu, dalam kodifikasi undang-undang hukum pidana jika dipandang hal itu memang diperlukan. Lihat, Wirjono Prodjodikoro, Tindak-Tindak Pidana Tertentu di Indonesia (Bandung: PT Refika Aditama, 2008), hlm. 15.

10 Lihat H. Mustagfirin, Op.Cit., hlm. 91.

11 Ibid. 
sesuatu yang bersifat pasti saja yang dapat dijadikan ukuran kebenaran. Dengan demikian, dalam kultur sistem hukum civil, hukum identik dengan undang-undang, sumber hukum adalah undang-undang, nilai-nilai bersumber dari undang-undang, oleh karena itu civil law system tidak mengakui hukum-hukum dan nilai-nilai yang hidup dalam masyarakat.

Legal gap yang ada di masyarakat dapat diatasi dengan menggunakan sistem hukum yang tidak tertulis. Di Indonesia, terdapat dua sistem hukum yang tidak tertulis, yakni sistem hukum adat dan sistem hukum Islam. ${ }^{12}$ Esin Orucu dalam tulisannya yang berjudul What is a Mixed Legal System: Exlusion or Expansion berpandangan bahwa tidak terdapat negara yang murni menganut sistem civil law maupun common law. ${ }^{13}$ Oleh karena itu, perpaduan antara dua sistem hukum atau lebih tidak dapat dihindarkan di negara hukum modern saat ini. Orucu menjelaskan lebih lanjut bahwa beberapa sistem hukum dapat saling bercampur karena relasi internasional dan menciptakan pengaruh signifikan pada sistem hukum di tiaptiap negara. ${ }^{14}$

Percampuran sistem hukum (mixed legal system) ini merupakan perkembangan dan klasifikasi klasik dari suatu sistem hukum. Terdapat beberapa contoh percampuran sistem hukum dan menyebutkan percampuran sederhana (simple mixes) antara sistem hukum civil law dan common law serta percampuran kompleks (complex mixes) antara kedua sistem hukum tersebut dengan hukum agama atau hukum adat. Di Indonesia, kehadiran sistem hukum Islam dan hukum adat dapat mengatasi ketersenjangan dari dianutnya sistem hukum civil.

\section{Hukum Islam dan Kedudukannya dalam Sistem Hukum di Indonesia}

\section{a. Legal Historis Pengakuan Hukum Islam di Indonesia}

Sejak masuknya agama Islam ke nusantara, dapat dikatakan bahwa secara empiris hukum Islam merupakan hukum yang hidup (the living law) dalam masyarakat Indonesia. ${ }^{15}$ Dalam catatan dari J.C. Van Leur, masuknya Islam ke Indonesia yang pada saat itu masih disebut sebagai "nusantara" dimulai pada abad ke-7 (tujuh) Masehi. ${ }^{16}$ Artinya, penerimaan hukum Islam oleh masyarakat terjadi pada fase awal lahirnya Islam di Jazirah Arab hingga masuknya kolonial Belanda. Meskipun demikian, penerimaan hukum Islam sebagai hukum yang hidup di masyarakat mengalami tantangan sejak masuknya Belanda.

12 Terminology “Hukum Islam” sendiri kadang menimbulkan ambiguitas, sehingga sering di satu sisi sering dairtikan sebagai syariah Islam, dan di sisi lain diartikan sebagai persamaan dari fiqh. Istilah Islamic Law mengacu pada al-syariah al-islamyah, sedangkan Islamic Jurispridence diterjemahkan sebagai al-fiqh al-islamy, dan kedua istilah tersebut dalam pandangan Islam memiliki pengertian yang berbeda, meskipun keduanya memiliki hubungan yang erat. Al-syariah al-islamiyah sering dihubungkan sebatas dengan hal-hal yang berkaitan dengan persoalan hukum yang dapat diaktualisasikan setelah bersinggungan dengan rasio manusia, yang kemudian diformulasikan sebgai al-fiqh al-islamy. Lihat Ahmad Rofiq, Pembaharuan Hukum Islam di Indonesia, (Yogyakarta: Gema Medua, 2001), hlm. 13.

13 Esin Orucu, "What is a Mixed Legal System: Exclusion or Expansion", Electronic Journal of Comparative Law, Vol.12, No.1, May (2008), hlm. 2

14 Ibid.

15 Said Agil Husein Al Munawwar, Islam dalam Pluralitas Masyarakat Indonesia, (Jakarta: Kaifa, 2004), hlm. 176.

16 Ahmad Mansur Suryanegara, Menemukan Sejarah, (Bandung: Mizan, 1999), hlm. 74-76. 
Pada masa pemerintahan VOC (Vereenigde Oost Indische Compagnie), diberlakukan aturan bahwa semua daerah dibawah kekuasaan VOC harus menggunakan hukum Belanda. Akan tetapi karena masyarakat lebih memilih menggunakan hukum Islam, maka pemerintah VOC memperbolehkan masyarakat menggunakan hukum Islam dalam menyelesaikan sengketa di masyarakat. Kemudian pada tahun 1760, pemerintah VOC melalui D.W. Freijer membuat Compedium Freijer yang dijadikan rujukan hukum untuk menyelesaikan masalah hukum masyarakat Islam di daerah yang dikuasai oleh VOC. $^{17}$

Pasca pemerintahan VOC, tantangan lain datang dari upaya paksaan untuk "mengkerdilkan" hukum Islam secara normatif oleh pemerintah Hindia-belanda melalui Staatsblad 1937 Nomor 116. Menurut Yahya Harahap, aturaninimerupakan hasil rekomendasi Ter Haar yang berisi antara lain: (1) Hukum waris Islam belum sepenuhnya diterima oleh masyarakat; (2) Mencabut wewenang Peradilan Agama (Raad Agama) untuk perkara waris dan dialihkan kepada Landraat; (3) Peradilan Agama (Raad Agama) dibawah pengawasan Landraat; dan (4) Putusan Peradilan Agama tidak dapat dilaksanakan tanpa executoir verklaring dari ketua Landraat. ${ }^{18}$

Jauh sebelum lahirnya Staatsblad 1937 Nomor 116, Hukum Islam sebenarnya sudah diimplementasikan dan dikembangkan oleh masyarakat dalam suatu peradilan agama. Peradilan agama secara formal telah ada sejak masa kesultanan dan kerajaan-kerajaan Islam di Indonesia, misalnya peradilan penghulu di Jawa, Mahkamah Syari'ah di Kesultaan Islam di Sumatera, serta adanya Peradilan Qadli di Kesultanan Banjar dan Pontianak. Pada tahun 1937, dikeluarkan Staatsblad 1937 Nomor 638 dan 639 yang mengatur tentang Kerapatan Qadli dan Kerapatan Qadli Besar untuk wilayah Kalimantan Selatan. Kerapatan Qadli dan Kerapatan Qadli Besar memiliki kewenangan selayaknya Peradilan Agama yang ada di Jawa dan Madura. Berdasarkan Staatsblad 1937 Nomor 116, Peradilan Agama memiliki batas kekuasaan, antara lain:

1. Perselisihan antara suami-isteri yang beragama Islam;

2. Perkara tentang nikah, talak, rujuk, dan perceraian bagi orang yang beragama Islam dan memerlukan perantara hakim beragama Islam;

3. Memberikan keputusan tentang perceraian;

4. Menyatakan bahwa syarat untuk jatuhnya talak yang digantungkan (taklik talak) sudah tidak ada;

5. Masalah tentang mahar;

6. Masalah tentang kebutuhan hidup isteri yang wajib diberikan oleh suami.

Penerimaan Hukum Islam secara normatif dan otoritatif dimulai sejak berlakunya UUD 1945. Menurut Ismail Sunny, berlakunya UUD 1945 dan Pancasila sebagai dasar negara meskipun tanpa memuat tujuh kata dari Piagam Jakarta ${ }^{19}$, menjadikan teori receptie (teori konflik) yang dikembangkan oleh Snouck Hurgronje kehilangan dasar hukumnya dan

17 Lihat Supomo dan Djoko Sutowo, Sejarah Politik Hukum Adat 1609 - 1848, (Jakarta: Djambatan, 1955$)$, hlm. 26.

18 M. Yahya Harahap, Informasi Materi Kompilasi Hukum Islam: Mempositifkan Abstraksi Hukum Islam, dalam Kompilasi Hukum Islam dan Peradilan Agama dalam Sistem Hukum Nasional, (Jakarta: Logos, 1999), hlm. 27.

19 Naskah asli Piagam Jakarta memuat pengakuan atas syariat Islam sebagai bagian dari dasar Negara yakni Ketuhanan, dengan kewajiban menjalankan Syariat Islam bagi pemeluk-pemeluknya. 
tidak berlaku. Sebaliknya, Hukum Islam justru semakin kuat diakui secara konstitusional dalam Pasal 29 UUD 1945. Pada masa tersebut, Hukum Islam diterima sebagai sumber persuasif (persuative source). ${ }^{20}$

Penerimaan Hukum Islam semakin besar pasca berlakunya otonomi daerah, dimana daerah mulai berlomba untuk mengatur sendiri segala urusan daerahnya masingmasing. Pemerintah daerah mengambil peluang ini untuk kemudian membentuk Peraturan Daerah berlandaskan ciri khas daerahnya. Banyak daerah terutama masyarakat yang menginginkan peraturan-peraturan daerah yang bernuansa Islam berlandaskan prinsip Syariah sesuai dengan kondisi sosiologis masyarakatnya. Salah satu daerah yang menginginkan peraturan bernuansa Syariah tersebut adalah Provinsi Aceh, dengan peraturan daerah yang disebut dengan Qanun.

Melalui Undang-Undang Nomor 11 Tahun 2006 tentang Pemerintahan Aceh, pemerintah telah memberikan kewenangan untuk Pemerintahan Aceh yang meliputi:

a) penyelenggaraan kehidupan beragama dalam bentuk pelaksanaan syari'at Islam bagi pemeluknya di Aceh dengan tetap menjaga kerukunan hidup antarumat beragama;

b) penyelenggaraan kehidupan adat yang bersendikan agama Islam;

c) penyelenggaraan pendidikan yang berkualitas serta menambah materi muatan lokal sesuai dengan syari'at Islam;

d) peran ulama dalam penetapan kebijakan Aceh; dan e) penyelenggaraan dan pengelolaan ibadah haji sesuai dengan peraturan perundangundangan.

Selain Qanun di Provinsi Aceh, lahir juga beberapa Lembaga Kenegaraan dan lembagalembaga lainnya yang bernafaskan agama Islam, misalnya Majelis Ulama Indonesia diikuti oleh pendirian badan-badan yang lain seperti Badan Amil Zakat Nasional dan Badan Wakaf Indonesia. Majelis Ulama Indonesia yang pertama kali didirikan adalah Majelis Ulama Jawa Barat pada tahun 1958. Majelis Ulama tingkat pusat didirikan pada tahun 1962, yang kemudian diikuti berbagai Majelis Ulama di tingkat provinsi. Pada tahun 1975, dibentuk Majelis Ulama baru dengan sebutan Majelis Ulama Indonesia (MUI). ${ }^{21}$ Bahkan, Majelis Ulama Indonesia memegang peran penting dalam menjamin terwujudkan kerukunan umat beragama melalui fatwa-fatwa yang diberikan.

\section{b. Konstribusi Hukum Islam dalam Perkembangan Hukum Positif di Indonesia}

Salah satu produk peraturan perundangundangan yang secara jelas mengakomodir nilai-nilai agama adalah Undang-Undang Nomor 1 Tahun 1974 tentang Perkawinan. Pasal 2 Undang-Undang Nomor 1 Tahun 1974 menempatkan agama sebagai penentu sahnya perkawinan, sehingga perkawinan di Indonesia menganut religious marriage. Adanya rumusan Pasal 2 UU Perkawinan tersebut memiliki konsekuensi logis bahwa semua Warga Negara Indonesia yang beragama Islam harus memenuhi ketentuan dari hukum Islam terlebih

20 Lihat, Ismail Sunny, Tradisi dan Inovasi Keislaman di Indonesia dalam Bidang Hukum Islam, dalam Hukum Islam dalam Tatanan Masyarakat Indonesia, Cik Hasan Bisri (ed), (Jakarta: Logos Publishing, 1988), hlm. 96.

21 Ahmad Sukardja, Piagam Madinan dan Undang-Undang Dasar NRI 1945, (Jakarta: Sinar Grafika, 2012 ), hlm. 209. 
dahulu agar perkawinannya dapat dikatakan sah secara agama. Hal ini membuktikan bahwa eksistensi hukum Islam masih sangat berpengaruh dalam kehidupan berbangsa dan bernegara di Indonesia.

Regulasi tentang zakat juga merupakan salah satu bukti lain mengenai eksistensi hukum Islam dalam kehidupan berbangsa dan bernegara di Indonesia. Pengaturan mengenai zakat pertama kali adalah melalui Surat Edaran Kementerian Agama Nomor A/VII/17367 tahun 1951, di mana surat edaran ini melanjutkan ketentuan ordonansi Belanda yang menyatakan bahwa negara hanya akan melakukan pengawasan, dan tidak akan mencampuri urusan pemungutan dan pembagian zakat. Pada tahun 1991 pemerintah mengeluarkan Surat Keputusan Bersama Menteri Dalam Negeri dan Menteri Agama Republik Indonesia Nomor 29 dan 47 Tahun 1991 tentang Pembinaan Badan Amil Zakat, Infaq, dan Shadaqah/ Pada tahun 1998, lahirlah Instruksi Menteri Dalam Negeri Nomor 7 tentaang Pembiaan Badan Amil Zakat dan Shadaqah. Saat ini, pengelolaan zakat daitur dalam Undag-Undnag Nomor 23 tahun 2011, yang merupakan hasil revisi dari Undang-Undang Nomor 38 Tahun 1999 tentang Pengelolaan Zakat.

Selain perkawinandanzakat, Undang-Undang Nomor 13 tahun 2008 tentang Penyelenggaraan Ibadah Haji juga merupakan salah satu bukti eksistensi hukum Islam di Indonesia. Pada Pasal 8 ayat (2) Undang-Undang Nomor 13 tahun 2008 menjelaskan bahwa kebijakan dan pelaksanaan dalam penyelenggaraan ibadah haji merupakan tugas nasional dan menjadi tanggung jawab pemerintah.
Undang-Undang Nomor 41 Tahun 2004 tentang Wakaf merupakan salah satu bentuk penerapan Hukum Islam dalam sistem hukum nasional yang isinya mengandung beberapa hal baru dan cukup penting, di antaranya masalah nazhir, maiquf bih (harta benda yang diwakafkan), mauquf 'alaih (peruntukan harta wakaf), dan juga perlunya dibentuk Badan Wakaf Indonesia. Dalam Pasal 28 ayat (2) UndangUndang Nomor 41 Tahun 2004 tentang Wakaf, disebutkan bahwa Badan Wakaf Indonesia dapat bekerja sama dengan instansi pemerintah baik di tingkat Pusat maupun Daerah, organisasi masyarakat, ahli, badan internasional, dan pihak lain apabila diperlukan.

Menariknya, terdapat juga pembukuan (kodifikasi) aturan hukum Islam dalam wadah Kompilasi Hukum Islam (KHI). KHI mengatur tentang berbagai hal yang berkaitan dengan hukum Islam, misalnya masalah waris yang diatur dalam Buku Kedua pada Kompilasi Hukum Islam, yang didasarkan pada ilmu Faraidl, yaitu ilmu mengenai ketentuan pembagian harta warisan dalam Islam. $\mathrm{KHI}$ terdiri atas 3 (tiga) buku yakni Buku I tentang Perkawinan, Buku II tentang Kewarisan,dan Buku III tentang Perwakafan.

\section{Kedudukan dan Eksistensi Hukum Adat dalam Sistem Hukum di Indonesia}

\section{a. Eksistensi Hukum Adat dalam Sistem Hukum di Indonesia}

Mason C. Hoadley dalam tulisannya The Leiden Legacy: Concepts of Law in Indonesia (Review) berpendapat bahwa Keberadaan hukum adat sebagai living law bangsa Indonesia semakin termarginalkan. ${ }^{22}$ Hukum adat yang

22 Mason C Hoadley, “The Leiden Legacy: Concepts of Law in Indonesia (Review)", Journal of Social Issues in Southeast Asia, Vol. 21 No. 1 April (2006). 
pada awalnya menjadi hukum yang hidup dan berkembang serta mampu memberikan solusi terhadap berbagai permasalahan hidup masyarakat Indonesia, semakin hilang eksistensinya. Saat ini, apabila melihat fakta empiris di masyarakat, dapat ditemui berbagai kompleksitas masalah yang dihadapi masyarakat adat di Indonesia terutama ketika hukum adat berhadapan dengan hukum positif. Sebagai contohnya, ketika hak-hak tradisional masyarakat berhadapan dengan kepentingan investor melalui sarana hukum negara. ${ }^{23}$ Perkembangan Sistem Hukum Indonesia yang cenderung lebih memilih model sistem hukum civil dari negara barat dan politik hukum Indonesia yang mengarah pada kodifikasi dan unifikasi hukum, mempercepat hilangnya eksistensi hukum adat dan pranata-pranatanya.

Semakin hilangnya eksistensi hukum adat sebagai salah satu sumber hukum di Indonesia, penyebabnya karena anggapan bahwa hukum adat sangat bersifat tradisional, tertinggal, dan kuno, sehingga tidak dapat menjangkau perkembangan zaman yang modern. Implikasi dari politik hukum Indonesia ini dapat dilihat dalam pemecahan permasalahan di masyarakat yang cenderung mengesampingkan hukum adat dan lebih mengutamakan hukum negara, meskipun sebenarnya lebih relevan daripada menggunakan hukum negara. Banyaknya konflik horizontal, antara masyarakat adat di satu wilayah yang seharusnya dapat diselesaikan melalui peran lembaga penyelesaian masyarakat adat. ${ }^{24}$ Masalah krusial yang timbul dalam keseharian adalah perbedaan persepsi antara penguasaan tanah oleh masyarakat berdasarkan hak ulayat dengan kepentingan umum yang menjadi beban dan kewajiban negara. ${ }^{25}$ Contoh lain adalah gagasan agar dasar patut dipidananya suatu perbuatan diperluas ke ranah nilai hukum adat. ${ }^{26}$

Padahal, apabila melihat legal historisnya, berlakunya hukum di Indonesia justru mencatat bahwa banyak para ahli hukum khususnya dari negara Barat cenderung tertarik mempelajari hukum adat sebagai hukum yang hidup di masyarakat Indonesia sejak ribuan tahun lamanya. Snouck Hurgronje misalnya, ahli pertama yang mempelajari hukum Indonesia, menulis buku yang berjudul De Atjehers menyebutkan istilah hukum adat sebagai adat recht untuk memberi nama pada satu sistem pengendalian sosial (social control) yang hidup dalam Masyarakat Indonesia. Selanjutnya teori Snouck Hurgronje dikembangkan oleh Cornelis van Vollenhoven yang kemudian dikenal sebagai pakar Hukum Adat di Hindia Belanda.

Mengingat hukum Adat adalah hukum yang mencerminkan kepribadian dan jiwa bangsa, maka diyakini bahwa sebagian pranata hokum Adat tentu masih relevan menjadi bahan dalam membentuk sistem hukum Indonesia. ${ }^{27}$ Hukum Adat yang tidak lagi dapat dipertahankan akan punah seiring berjalannya waktu, sesuai dengan

23 M. Syamsudin, "Beban Masyarakat Adat Menghadapi Hukum Negara”, Jurnal Hukum, Vol. 15 No. 3 Juli (2008), hlm. 338-351.

24 J. Sahalessy, “Peran Latupati Sebagai Lembaga Hukum Adat Dalam Penylesaian Konflik Antar Negeri Di Kecamatan Leihitu Propinsi Maluku”, Jurnal Sasi, Vol. 17 No. 3 Juli-September (2011), hlm. 45.

25 Rosmidah, "Pengakuan Hukum Terhadap Hak Ulayat Masyarakat Hukum Adat Dan Hambatan Implementasinya”, Inovatif, Jurnal Ilmu Hukum Vol. 2 No. 2, (2010).

26 Reimon Supusesa, "Eksistensi Hukum Delik Adat dalam Perspektif Pembaharuan Hukum Pidana Di Maluku Tengah", Jurnal Mimbar Hukum Vol. 24, No. 1 Februari (2012), hlm. 1-186.

27 Ratna Winahyu Lestari Dewi, "Peranan Hukum Adat dalam Pembangunan Dan Pembangunan KUHP Nasional", Jurnal Perspektif, Vol. X No. 3 Edisi Juli (2005). 
sifat hukum adat yang fleksibel dan dinamis (tidak statis). Menurut Von Savigny sebagaimana dikutip oleh Soepomo menegaskan bahwa Hukum Adat adalah hukum yang hidup, karena merupakan penjelmaan perasaan hukum yang nyata dari rakyat. Sesuai fitrahnya sendiri, hukum adat terus menerus dalam keadaan tumbuh dan berkembang seperti hidup itu sendiri. ${ }^{28}$ Sependapat dengan Savigny, van Vollenhoven mengatakan bahwa hukum adat pada waktu yang telah lampau agak beda isinya, hukum adat menunjukkan perkembangan. Selanjutnya Vollenhoven menegaskan bahwa hukum adat berkembang dan maju terus, keputusankeputusan adat menimbulkan hukum adat.

Apabila berlakunya suatu undang-undang bertentangan dengan nilai-nilai dan normanorma hukum yang hidup dan berlaku dalam masyarakatnya, tentunya akan mendapat penolakan. Dalam konteks Indonesia, living law masyarakat Indonesia adalah hokum Adat. Hukum adat juga dapat dijadikan sebagai sumber hukum oleh hakim jika undang-undang memerintahkan demikian. ${ }^{29}$ Hukum Adat merupakan hokum yang tidak dikodifikasi di kalangan bangsa Indonesia dan Timur asing (antara lain Tionghoa dan Arab).

Sedangkan untuk menganalisa kedudukan hukum adat dalam sistem hukum perlu kiranya diperhatikan salah satu aliran alam ilmu hukum yaitu, Sociological Jurisprudence yang disampaikan oleh Eugen Ehrlich. Konsepsi dasar dari pemikiran Ehrlich tentang hukum adalah apa yang dinamakan dengan living law. Hukum positif yang baik dan efektif adalah hukum yag sesuai dengan living law dari masyarakat yang mencerminkan nilai-nilai yang hidup di dalamnya.

Pesan Ehrlich pada pembuat undangundang adalah dalam membuat undangundang hendaklah diperhatikan apa yang hidup dalam masyarakat. Adalah suatu kenyataan dan tidak dapat dipungkiri bahwa hukum adat yang berlaKu di Indonesia pada umumnya dan Provinsi Aceh pada khusunya adalah hukum yangi sudah sesuai dengan nilai-nilai yang hidup dalam masyarakat. Oleh karena itu agar hukum adat dapat efektif berlaku dalam masyarakat maka dalam pembentukan undang-undang dan Qanun di Aceh, wakil rakyat yang duduk di lembaga legislative harus mampu menggali dan wajib menampung kesadaran hukum yang hidup dalam masyarakat. Kesadaran hukum masyarakat yang telah diformalkan baik dalam undangundang maupun qanun akan dapat digunakan sebagai dasar dalam menjaga ketertiban dan kerukunan hidup masyarakat.

\section{b. Kompleksitas Pengakuan Hukum Adat sebagai Hukum yang Hidup di Indonesia}

Pemerintah Kolonial Belanda mengakui hukum adat secara resmi sebagai hukum asli Indonesia dan sejajar dengan hukum Eropah melalui Pasal 131 ayat (6) IS yang menyatakan "hukum bangsa Indonesia adalah hukum positif bagi bangsa Indonesia". Pengertian hukum Bangsa Indonesia dalam pasal tersebut adalah hukum adat. Pasal 131 ayat (6) ini merupakan payung hukum terhadap pengakuan Pemerintah Hindia Belanda terhadap hukum adat dan sekaligus pengakuan terhadap hukum adat sebagai hukum positif yang hidup bagi bangsa

28 Soepomo dan Djoko Suwono, Loc.Cit.

29 Sulastriyono dan Aristya, "Penerapan norma dan Asas-Asas Hukum Adat Dalam Praktik Peradilan Perdata", Jurnal Mimbar Hukum, Vol. 24 No. 1 Februari (2012). 
Indonesia. Diakuinya hukum adat sebagai hukum positif maka pada masa Pemerintahan Hindia Belanda, maka ada dua sistem hukum yang berlaku yaitu sistem hukum Belanda bagi orang Eropah dan bagi orang Timur Asing maupun orang Indonesia yang secara penundukan diri kepadanya diberlakukan hukum Eropah (Pasal 131 ayat (2) IS) dan hukum adat bagi bangsa Indonesia dan orang timur asing yang tidak asing di Indonesia (Pasal 136 ayat (6) IS).

Pasca Kemerdekaan, pengakuan terhadap hukum tidak tertulis hanya dijelaskan atau dicantumkan dalam Penjelasan Umum UUD 1945 angka I yang menyebutkan "... UndangUndang Dasar ialah hukum dasar yang tertulis, sedang di sampingnya Undang-undang Dasar itu berlakunya juga hukum dasar yang tidak tertulis, ialah aturan-aturan dasar yang timbul dan terpelihara dalam praktik penyelenggaraan negara meskipun tidak tertulis". Selanjutnya, dalam Pasal 18B ayat (2) Amandemen UUD 1945 menyebutkan "Negara mengakui dan menghormati kesatuan-kesatuan masyarakat hukum adat beserta hak-hak tradisionalnya sepanjang masih hidup dan sesuai dengan perkembangan masyarakat dan prinsip Negara Kesatuan Republik Indonesia, yang diatur dalam undang-undang". Menurut pasal ini hukum adat yang diakui adalah hukum adat yang masih nyata-nyata hidup, jelas materi dan lingkup masyarakat adatnya.

Ketentuan Pasal 18B ayat (2) di atas dapat dipahami bahwa UUD 1945 lebih mengutamakan hukum yang tertulis daripada hukum tidak tertulis. Artinya, pengakuan terhadap hukum adat yang masih hidup dalam masyarakat di suatu daerah harus dilakukan dengan pengaturan dalam peraturan perundangundangan (tertulis) dan sejalan dengan prinsip Negara Kesatuan Republik Indonesia. Hal ini diperkuat oleh Mahkamah Konstitusi melalui Putusan Nomor 31/PUU-V/2007 tentang Pengujian Undang-Undang Nonor 31 Tahun 2007 tentang Pembentukan Kota Tual di Provinsi Maluku. Dalam putusan tersebut, Mahkamah Konstitusi menentukan empat syarat konstitusionalitas kesatuan masyarakat hukum adat dalam Pasal 18B ayat (2) UUD 1945, antara lain: (1) masih hidup; (2) sesuai dengan perkembangan masyarakat; (3) sesuai dengan prinsip negara Kesatuan Republik Indonesia; (4) diatur dalam undang-undang. Bahkan, apabila syarat ini tidak terpenuhi, masyarakat adat tidak dapat menjadi pihak berperkara di Mahkamah Konstitusi karena dianggap tidak memiliki legal standing. ${ }^{30}$

Dalam pertimbangan Putusan Nomor 31/PUU-V/2007 tersebut, Mahkamah Konstitusi menegaskan bahwa "...pengakuan keberadaan masyarakat hukum adat sebagai penyandang hak atau sebagai subjek hukum merupakan hak fundamental. Hal penting dan fundamental tersebut adalah masyarakat hukum adat tersebut secara konstitusional diakui dan dihormati sebagai penyandang hak yang demikian tentunya dapat pula dibebani hukum di dalam suatu masyarakat yang telah menegara maka masyarakat hukum adat haruslah mendapat perhatian sebagaimana subjek hukum yang lain ketika hukum hendak mengatur, terutama mengatur dalam rangka pengalokasian sumber-sumber kehidupan." Ketentuan Pasal 18B ayat (2) UUD 1945 dan Putusan Nomor 31/PUU-V/2007 ini secara

\footnotetext{
Lihat Zaka Firma Aditya dan Sholahuddin AL-Fatih, "State Liability for Violation of Constitutional Rights Against Indegenous People in Freedom of Religion and Belief", Brawijaya Law Journal, Volu. 4 No. 1 (2017), hlm. 37.
} 
normatif memang memberi pengakuan terhadap keberadaan hukum adat, namun di sisi yang lain juga memberikan pembatasan terhadap masyarakat adat dan hukum adat mana saja yang dapat diakui oleh negara.

\section{c. Konstribusi Hukum Adat dalam Perkembangan Yurisprudensi}

Hukum adat juga memiliki peran strategis dalam pembentukan yurisprudensi hukum oleh hakim di pengadilan. Selain merupakan keputusan pengadilan yang telah menjadi tetap dalam bidang hukum adat, yurisprudensi yang didasari oleh nilai-nilai hukum adat juga merupakan sarana pembinaan hukum adat. Perkembangan-perkembangan hukum adat melalui yurisprudensi dapat memberikan pengetahuan tentang pergeseran dan tumbuh berkembangnya hukum adat. Peran hukum adat dalam pembentukan yurisprudensi dapat dilihat dalam beberapa hal, yakni:

1. Yurisprudensi dalam Bidang Perdata

a. Prinsip Hukum Adat.

Hukum adat antara lain bersandarkan pada azas: rukun, patut, laras, hal ini ditegaskan dalam yurisprudensi Mahkamah Agung-RI Nomor: 3328/Pdt/1984 tanggal 29 April 1986. Dalam Putusan MA-RI Nomor 2898 K/Pdt/1989 tanggal 19 Nomember 1989, berdasarkan sengketa adat yang timbul di Pengadilan Kefamenanu, Nusa Tenggara Timur, Mahkamah Agung menegaskan pentingnya menerapkan hukum adat, yakni:

"Dalam menghadapi kasus gugatan perdata yang fondamentum petendi dan petitumnya berdasarkan pada pelanggaran hukum adat dan penegasan sanksi adat; Bila dalam persidangan penggugat dapat membuktikan dalil gugatannya, maka hakim harus menerapkan hukum adat mengenai pasal tersebut yang masih berlaku di daerah bersangkutan, setelah mendengar Tetua adat setempat". Kaedah hukum selanjutnya:
"Penyelesaian pelanggaran hukum adat, disamping melalui gugatan perdata tersebut di atas, dapat pula ditempuh melalui tuntutan pidana ig pasal 5 (3)b UU No. 1 Drt/1951“.

b. Menguatnya Kedudukan Keluarga Inti (Gezin)

Pada umumnya, golongan masyarakat adat di Indonesia terdiri dari golongan masyarakat patrilineal, matrilineal, dan parental/bilateral. Dalam Perkembangannya ternyata semakin kuat dan diakuinya pergeseran sistem kekeluargaan dalam masyarakat adat patrilineal dan masyarakat adat matrilineal ke arah sistem parental/bilateral. Yurisprudensi tanggal 17 Januari 1959b Nomor 320K/ Sip/ 1958 menyatakan bahwa:

1) Si istri dapat mewarisi harta pencaharian sang suami yang meninggal dunia;

2) Anak yang belum dewasa dipelihara dan berada dalam pengampuan ibu;

3) Karena anak berada dalam pengampuan ibu, maka harta kekayaan anak dikuasai dan diurus oleh ibu.

4) Kedudukan sama laki dan perempuan.

c. Kedudukan Janda dalam Hukum Waris.

Pada awalnya disebutkan bahwa seorang janda bukan ahli waris, namun dalam kenyataannya si janda menjadi sangat menderita setelah ditinggal suaminya. Oleh karenanya, maka muncul praktik pemberian hibah oleh suami kepada istri untuk melindungi dan mempertahankan kehidupan sosial ekonomi sepeninggal suaminya. Perkembangan hukum adat berikutnya adalah bahwa janda sebagai ahli waris bersama sama dengan anak-anak almarhum suaminya. Selanjutnya janda sebagai ahli waris yang kedudukannya sama dengan ahli waris anak. Perkembangan selanjutnya janda sebagai ahli waris kelompok keutamaan, yang menutup ahli waris lainnya. 
Pada Yurisprudensi Putusan MA No. 387K/ Sip/1956 tanggal 29 Okt0ber 1958, Janda dapat tetap menguasai harta gono gini sampai ia meninggal dunia atau kawin lagi. Kemudian pada Yurisprudensi Putusan Mahkamah Agung No. 3190K/Pdt/'985, tanggal 26 Oktober 1987, janda memiliki hak waris dari harta peninggalan suaminya, dan haknya sederajad dengan anak kandungnya, apabila tidak memiliki anak, maka ia jadi penghalang ahli waris saudara suaminya, terhadap harta gawan dan harta gono gini.

\section{Yurisprudensi dalam Hukum Pidana Adat.}

Dalam sistem hukum adat, tidak dikenal pemisahan hukum pidana dengan hukum lain sebagaimana dalam tradisi hukum barat. Penjatuhan pidana hanya dilakukan untuk menetapkan hukumnya (verklaring van recht) berupa sanksi adat (adat reaktie), dan mengembalikan hukum adat yang dilanggar. Hukum pidana adat mendapat rujukan berlakunya dalam pasal 5 ayat (3) UU No. 1/ Drt/1951. Adapun Yurisprudensi penting mengenai Hukum pidana adat diantaranya:

a. Perbuatan melawan Hukum.

Pada putusan PN Luwuk No. 27/Pid/ 1983 merupakan putusan yang mengadili perkara hubungan kelamin di luar perkawinan. Hakim memutus terdakwa melanggar hukum yang dihupo di wilayah banggai, Sulawesi Tengah, dan berdasarkan unsur pidana dalam pasal 5 ayat (3) sub b UU Drt 1/ drt/1951, yakni: (1) suatu perbuatan melanggar hukum yang hidup; (2) perbuatan pelanggaran tersebut tidak ada bandingannya dalam KUHP; (3) perbuatan pelanggaran tersebut masih tetap berlaku untuk kaula-kaula dan oarngorang yang bersangkutan. Putusan PT Palu No. 6/Pid/1984 tanggal 9 April 1984 ternyata menguatkan putusan PN Luwuk, dengan menambahkan bahwa untuk memenuhi rasa keadilan masyarakat, yang menganggap perbuatan tersebut adalah perbuatan pidana, hakim memutuaskan terdakwa tela h melakukan kejahatan bersetubuh dengan seorang wanita di luar nikah. Mahkamah Agung, dengan putusan No. 666K/ Pid/ 1984 tanggal 23 februari 1985 menyatakan bahwa perbuatan yang dilakukan terdakwa dikategorikan sebagai perbuatan zina menurut hukum adat. Mahkamah Agung dalam putusan Nomor 3898K/Pdt/1989, tanggal 19 Nopember 1992 berpandangan bahwa mengenai pelanggaran adat serupa di daerah Kafemenanu, namun diajukan secara perdata dengan gugatan yang pada pokoknya: apabila dua orang dewasa melakukan hubungan kelamin atas dasar suka sama suka yang mengakibatkan si perempuan hamil, dan si laki-laki tidak bertanggung jawab atas kehamilan tersebut, maka harus ditetapkan suatu sanksi adat berupa pembayaran belis (biaya atau mas kawin) dari pihak laki-laki kepada pihak perempuan (Pualeu Manleu).

b. Perbuatan melanggar hukum adat Logika Sanggraha di Bali.

Dalam perkara Nomor 854K/Pid/1983 tanggal 30 Oktober 1984, Mahkamah Agung berpandangan bahwa seorang laki-laki yang tidur bersama dengan seorang perempuan dalam satu kamar dan pada satu tempat tidur, merupakan bukti petunjuk bahwa lakilaki tersebut telah bersetubuh dengan wanita itu. Berdasarkan keterangan saksi korban dan adanya bukti petunjuk dari para saksi-saksi lainnya, terdakwa telah bersetubuh dengan saksi korban sebagaimana dimaksud dalam dakwaan subsider. 


\section{Pluralisme Hukum Menciptakan Romantisme Hukum di Indonesia}

Pluralisme hukum yang ada di Indonesia, meskipun sebagai hukum tidak tertulis justru mampu menjadi pemersatu, dan menjadi solusi bahkan menciptakan ketentraman dalam pergaulan hidup masyarakat. Pluralisme hukum di Indonesia secara dinamis mengikuti perkembangan masyarakatnya dengan tetap bertumpu pada karakteristik masyarakat adat dan pola pikir participerend coschmish menarik minat para pakar dari penjuru dunia untuk dijadikan objek penelitian. Bahkan, saat ini nilai hukum adat digunakan dalam penyelesaian sengketa baik perdata maupun pidana dengan berkembangnya metode atau pendekatan yang dikenal dengan pendekatan restoratif (restorative approach) ${ }^{31}$, yang hampir mirip dengan pendekatan participerend coschmish yang dianut oleh masyarakat adat. Implementasi pemulihan keadaan keseimbangan berdasarkan pola pikir participerend coschmish tersebut, menjelma dalam beberapa upacara, pantangan atau ritus (rites de passage). ${ }^{32}$

Fakta ini sedikit menunjukkan bahwa konsepsi dan pola pikir hukum yang hidup di masyarakat ternyata bukan saja masih relevan, melainkan menjadi inspirasi bagi negaranegara lain untuk mengembangkan hukum guna memenuhi rasa keadilan masyarakat. Masyarakat adat memiliki pola yang sama dalam menyelesaikan konflik di masyarakat, yakni mengontrol kehidupan dalam masyarakat dan menjatuhkan sanksi jika dilanggar sehingga pemulihan menjadi sangat efektif. ${ }^{33}$ Contoh lain, Universitas Utrecht berupaya mendorong digunakannya musyawarah mufakat model masyarakat adat Melayu dalam menyelesaikan permasalahan yang terjadi.

Dalam masyarakat Adat dan masyarakat Islam, penyelesaian sengketa melalui musyawarah merupakan hukum yang hidup dan dikenal hampir di setiap lingkaran hukum (rechtskring). Penyelesaian sengketa melalui musyawarah ini selalu melibatkan kepala rakyat (ketua adat), baik dalam mencegah adanya pelanggaran hukum (preventieve rechtszorg) maupun memulihkan hukum (rechtsherstel). ${ }^{34}$ Sebaliknya, Indonesia memberlakukan Undangundang Nomor 30 tahun 1999 Tentang Arbitrase dan Alternatif Penyelesaian Sengketa sebagai pilihan penyelesaian di luar pengadilan, yang secara nyata terinspirasi oleh perkembangan penyelesaian sengketa di negara dengan common law system.

Pentingnya hukum adat termasuk di dalamnya hukum Islam dalam menertibkan kehidupan masyarakat, maka diperlukan suatu upaya untuk melibatkan hukum Adat dan hukum Islam sebagai bagian dari sumber pembentukan hukum nasional. Dalam pandangan Mochtar Kusumaatmadja, hukum itu harus peka terhadap perkembangan masyarakat dan bahwa hukum itu harus disesuaikan dan menyesuaikan diri dengan keadaan. Dalam teori hukum progresif,ditegaskan bahwa suatu proses pembentukan peraturan perundangundangan adalah mutlak harus memperhatikan nilai-nilai dan norma-norma hukum yang hidup dan berlaku dalam masyarakat (living law).

\footnotetext{
Romli Atmasasmita, Globalisasi Kejahatan Bisnis, (Jakarta: Kencana Prenada Media Group, 2010), hlm. 190.

2 Bushar Muhammad, Asas Asas Hukum Adat-Suatu Pengantar, (Jakarta: Pradnya Paramita, 2002), hlm. 47.

33 Desi Tamarasari, "Pendekatan Hukum Adat Dalam Menyelesaikan Konflik Masyarakat Pada Daerah Otonomi", Jurnal Kriminologi Indonesia Vol. 2 No. 1 Januari (2002), hlm. 37-47.

34 Soepomo, Bab-Bab Tentang Hukum Adat, (Jakarta:Pradnya Paramita, 2003), hlm. 70.
} 
Romantisme keberlakuan hukum adat, hukum Islam dan hukum negara (civil law) dapat dilihat dari saling harmonisnya ketiga sistem hukum tersebut. Sebagaimana telah dijelaskan sebelumnya bahwa penerapan hukum civil yang kaku dan statis telah memunculkan legal gap di masyarakat. Legal tersebut dapat diatasi dengan menggunakan sistem hukum yang tidak tertulis yang fleksibel senantiasa mengikuti perkembangan zaman, yakni melalui normanorma dan nilai-nilai dari hukum adat dan hukum Islam. Von Savigny dalam mahakaryanya berjudul Von BerufUnsererZeitfur Gesetzgebung und Rechtswisseschaft mengatakan bahwa hukum itu tidak dibuat, akan tetapi tumbuh dan berkembang bersama masyarakat (Das Recht wird nicht gemacht, est ist und wird mit dem volke). Hukum adat dan hukum Islam telah tumbuh dan berkembang di masyarakat jauh sebelum diberlakukannya hukum civil. Bahkan, pembangunan hukum Indonesia saat ini tidak lepas dari nilai-nilai yang terkandung dalam Hukum adat dan hukum Islam.

\section{Penutup}

Hukum civil yang diadopsi Indonesia yang prinsip utamanya adalah mempositipkan hukum dalam bentuk aturan tertulis atau dituangkan dalam bentuk undang-undang secara teoritik tidak mengakui hukum yang tidak tertulis. Akan tetapi, sistem hukum civil ini dalam prakteknya memiliki banyak kelemahan karena sifatnya yang tertulis sehingga menjadi tidak fleksibel dalam mengikuti perkembangan masyarakat, cenderung kaku dan statis. Kekakuan dalam bentuk aturan tertulis dapat dikatakan merupakan bentuk pembatasan atas suatu hal yang sifatnya abstrak atau pembatasan dalam kontek materi dan dinamis atau pembatasan dalam dimensi waktu. Oleh karena itu, value consciousness masyarakat ke dalam undangundang secara logis akan membawa suatu ketertinggalan substansi undang-undang. Penerapan hukum civil yang totalitas juga pada akhirnya memunculkan legal gap di masyarakat. Legal gap yang ada di masyarakat tersebut hanya dapat diatasi dengan menggunakan sistem hukum yang tidak tertulis, yakni dengan hukum adat ataupun hukum Islam.

Hukum Islam sebagai bagian dari hukum yang hidup di masyarakat Indonesia sejak ratusan tahun lalu ternyata telah mempengaruhi corak hukumdilndonesia. Halinidikarenakanmayoritas penduduk di Indonesia menganut agama Islam yang memungkinkan hukum Islam menjadi bagian yang penting dan berpengaruh dalam sistem hukum di Indonesia. Adanya peraturan perundang-undangan yang bernafaskan Syariah Islam seperti dalam UU penyelengaraan Haji, UU Perbankan Syariah, UU Wakaf, UU Zakat, Kompilasi Hukum Islam (KHI) dan Peraturan Daerah Syariah (Perda Syariah) telah cukup membuktikan bahwa negara Indonesia tidak melepaskan tanggungjawab urusan beragama dengan urusan negara/pemerintah. Selain itu, dibentuknya lembaga-lembaga bernuansa Islam seperti Badan Amil Zakat Nasional (Baznas), Badan Wakaf Indonesia, Kementerian Agama, Peradilan Agama, Bank Syariah dan Majelis Ulama Indonesia menunjukan bahwa hukum Islam telah berkembang selaras mengikuti perkembangan zaman bersama hukum negara.

Hukum Adat sebagai hukum asli Indonesia mengalami masa fluktiasi dengan semakin hilangnya eksistensi hukum adat sebagai salah satu sumber hukum di Indonesia. Penyebabnya utamanya karena anggapan bahwa hukum adat sangat bersifat primitif, tertinggal, dan kuno. Implikasi dari politik hukum Indonesia ini dapat dilihat dalam pemecahan permasalahan di 
masyarakat yang cenderung mengesampingkan hukum adat dan lebih mengutamakan hukum negara, meskipun sebenarnya lebih relevan daripada menggunakan hukum negara. Banyaknya konflik horizontal, antara masyarakat adat di satu wilayah yang seharusnya dapat diselesaikan melalui peran lembaga penyelesaian masyarakat adat. Namun, seiring perkembangan waktu, kebutuhan akan nilai-nilai hukum adat menjadi semakin penting mengingat sistem hukum civil Indonesia mengalami banyak permasalahan karena sifatnya yang kaku dan statis. Bahkan, Hukum adat memiliki peran strategis dalam pembentukan yurisprudensi hukum oleh hakim di pengadilan.

Pluralisme hukum yang ada di Indonesia dapat menjadi solusi adanya legal gap yang tercipta karena kekakuan penerapan hukum civil. Kekakuan tersebut dapat diatasi dengan fleksibelitas dari norma dan nilai yang terdapat dalam hukum adat dan hukum Islam, sehingga menciptakan romantisme dalam kehidupan bermasyarakat.

\section{Daftar Pustaka}

\section{Buku}

Ahmad, Ansori, Sejarah dan Kedudukan BW di Indonesia, (Jakarta: Rajawali, 1986).

Al Munawwar, Said Agil Husein, Islam dalam Pluralitas Masyarakat Indonesia, (Jakarta: Kaifa, 2004).

Atmasasmita, Romli, Globalisasi Kejahatan Bisnis, (Jakarta: Kencana Prenada Media Group, 2010).

Cruz, Peter, Perbandingan Sistem Hukum Common Law, Civil Law, and Socialist Law, (Nusa Media: Bandung, 2010).

Hamzah, Andi, Asas-Asas Hukum Pidana, (Jakarta: PT. Rinek Cipta, 2010).

Harahap, M. Yahya, Informasi Materi Kompilasi Hukum Islam: Mempositifkan Abstraksi Hukum Islam, dalam Kompilasi Hukum Islam dan Peradilan Agama dalam Sistem Hukum Nasional, (Jakarta: Logos, 1999).
Marzuki, Peter Mahmud, Penelitian Hukum (Jakarta: Kencana Media Group, 2014).

Merryman, John Henry, The Civil Law tRadition An Introduction to The Legal System of Western Europe and Latin America, Second Etidion, (Stanford-Carolina: Standford University Press, 1985).

Muhammad, Bushar, Asas Asas Hukum Adat-Suatu Pengantar, (Jakarta: Pradnya Paramita, 2002).

Prodjodikoro, Wirjono, Tindak-Tindak Pidana Tertentu di Indonesia (Bandung: PT Refika Aditama, 2008).

Rofiq, Ahmad, Pembaharuan Hukum Islam di Indonesia, (Yogyakarta: Gema Medua, 2001).

Soepomo, Bab-Bab Tentang Hukum Adat, (Jakarta:Pradnya Paramita, 2003).

Sukardja, Ahmad, Piagam Madinan dan UndangUndang Dasar NRI 1945, (Jakarta: Sinar Grafika, 2012).

Sunny, Ismail, Tradisi dan Inovasi Keislaman di Indonesia dalam Bidang Hukum Islam, dalam Hukum Islam dalam Tatanan Masyarakat Indonesia, Cik Hasan Bisri (ed), (Jakarta: Logos Publishing, 1988).

Supomo dan Sutowo, Djoko, Sejarah Politik Hukum Adat 1609 - 1848, (Jakarta: Djambatan, 1955).

Suryanegara, Ahmad Mansur, Menemukan Sejarah, (Bandung: Mizan, 1999).

Syafiie, Inu Kencana, Sistem Adminitrasi Negara Republik Indonesia (SANRI), (Jakarta: Bumi Aksara, 2003).

\section{Makalah/Artikel/Prosiding/Hasil Penelitian}

Aditya, Zaka Firma dan Al-Fatih, Sholahuddin, "State Liability for Violation of Constitutional Rights Against Indegenous People in Freedom of Religion and Belief", Brawijaya Law Journal, Vol. 4 No. 1 (2017).DOI: http://dx.doi.org/10.21776/ ub.blj.2017.004.01.02

Dewi, Ratna Winahyu Lestari, "Peranan Hukum Adat dalam Pembangunan Dan Pembangunan KUHP Nasional", Jurnal Perspektif, Vol. X No. 3 Edisi Juli (2005).

H. Mustaghfirin, "Sistem Hukum Barat, Sistem Hukum Adat, Dan Sistem Hukum Islam Menuju Sebagai Sistem Hukum Nasional Sebuah Ide Yang Harmoni", Jurnal Dinamika Hukum, Volume 11, Edisi Khusus Februari (2011).

Hoadley, Mason C., "The Leiden Legacy: Concepts of Law in Indonesia (Review)", Journal of Social 
Issues in Southeast Asia, Vol. 21 No. 1 April (2006).

Orucu, Esin, "What is a Mixed Legal System: Exclusion or Expansion", Electronic Journal of Comparative Law, Vol.12, No.1, May (2008).

Rosmidah, "Pengakuan Hukum Terhadap Hak Ulayat Masyarakat Hukum Adat Dan Hambatan Implementasinya", Inovatif, Jurnal IImu Hukum Vol. 2 No. 2, (2010).

Sahalessy, J., "Peran Latupati Sebagai Lembaga Hukum Adat Dalam Penylesaian Konflik Antar Negeri Di Kecamatan Leihitu Propinsi Maluku", Jurnal Sasi, Vol. 17 No. 3 Juli-September (2011).
Sulastriyono dan Aristya, "Penerapan norma dan Asas-Asas Hukum Adat Dalam Praktik Peradilan Perdata", Jurnal Mimbar Hukum, Vol. 24 No. 1 Februari (2012).

Supusesa, Reimon, "Eksistensi Hukum Delik Adat dalam Perspektif Pembaharuan Hukum Pidana Di Maluku Tengah", Jurnal Mimbar Hukum Vol. 24, No. 1 Februari (2012).

Syamsudin, M., "Beban Masyarakat Adat Menghadapi Hukum Negara", Jurnal Hukum, Vol. 15 No. 3 Juli (2008).

Tamarasari, Desi, "Pendekatan Hukum Adat Dalam Menyelesaikan Konflik Masyarakat Pada Daerah Otonomi", Jurnal Kriminologi Indonesia Vol. 2 No. 1 Januari (2002). 